\title{
How far will English go?
}

ET goes shopping in this issue as Dilia Hasanova looks at shop signs and business names in Uzbekistan. Ulker Shafiyeva and Sara Kennedy describe the impact of English in another central Asian state: Azerbaijan. Foreign language teaching and language policy were political tools in the Soviet era and developments in English teaching, and the use of English today, reflect the complex political, social and economic changes in post-Soviet Azerbaijan.

English in Europe increasingly plays a national, and not just international, role, as our next three articles show. Keith Davidson updates us on the long-running story of English in Switzerland. Has Switzerland now become so globalised that English should be given some kind of semi-official status? It is the kind of proposal which meets with great resistance in Switzerland, but never quite goes away. Alison Edwards argues that Dutch English must now be regarded as a distinctive variety, joining the pantheon of World Englishes and quotes our founding editor, Tom McArthur, who announced at a conference in Amsterdam in 1993 that 'English is simply one of your languages, along with Dutch and Frisian'. Mikko Laitinen tells us that over $60 \%$ of Finns now feel that English plays an important role in their lives, and he is helping compile a 'corpus of English in Finland' which will examine the changing use of English there.

But if you want to see how English fares in a truly complex linguistic and cultural context, you probably need to go to Cameroon. Kelen Ernesta Fonyuy explores the impact of globalisation on the status of English there, and the problems in developing national language policy in a country which has 279 indigenous languages, two colonial languages (English and French) and its own variety of Cameroon Pidgin English.
And so to Dubai, where Mick Randall and Mohammad Amir Samimi document the transition from Arabic to English as the lingua franca. The UAE has an unusually large expatriate population - speaking an estimated 100 languages. As the authors point out 'the necessity of English as a means of communication in daily life makes Dubai a pertinent site for the study of ELF' (English as a Lingua Franca) and they conclude that it is likely that the language will continue to spread despite the concerns of many about the implications that this will have on Arabic'.

Like so many previous issues of English Today, ET101 documents the apparently irresistible rise of English as a global language and its linguistic, social, political and economic consequences. It is only right that we provide space for contributors who express anxieties about such a trend. Jeffrey Gil reminds us that Australians still need to learn foreign, especially Asian, languages and defends a recent policy report which argues for this. In his view, the number of English speakers around the world has been exaggerated, and the continuing need for other languages under-estimated. This argument, that monolingual Englishspeakers will be at a disadvantage in an increasingly multilingual world, is a theme we are likely to hear more of in the coming decade.

Indeed, Salikoko S. Mufwene warns us of exactly that in the second ET Column. He asks an important question. 'Is the world Anglicizing really as fast and/or globally as some language activists think?' Trying to buy food around the world using only English quickly shows whether English has reached beyond a country's professional elites.

Finally, Alexander Tulloch leads us down the etymological trail of drug use, a journey with some surprising twists involving assassins and daffodils.

The editorial policy of English Today is to provide a focus or forum for all sorts of news and opinion from around the world. The points of view of individual writers are as a consequence their own, and do not reflect the opinion of the editorial board. In addition, wherever feasible, ET generally leaves unchanged the orthography (normally British or American) and the usage of individual contributors, although the editorial style of the journal itself is that of Cambridge University Press. 